\title{
Users' Satisfaction with Reference Services in University Libraries in Nigeria: A Case Study
}

\section{Loveth Ogoegbunam Ekwueme*, Promise Ilo**, Goodluck Ifijeh***, Michael Fagbohun****,John D osa*****}

\author{
Author's Affiliation: \\ *National Open University of Nigeria, Jabi - A buja, Nigeria. \\ E-mail: lekwueme@noun.edu.ng \\ **Pamo University of Medical Sciences, Port Harcourt, Nigeria \\ E-mail: pilo@pums.edu.ng \\ ***Covenant University, Ota, Nigeria \\ E-mail: goodluck.ifijeh@covenantuniversity.edu.ng \\ * ${ }^{*}$ * Covenant University, Ota, Nigeria \\ E-mail: michael.fagbohun@covenantuniversity.edu.ng \\ * \\ E-mail: john.dosa@covenantuniversity.edu.ng
}

Corresponding A uthor: G oodluck Ifijeh, Covenant University, Ota, Nigeria

E-mail: goodluck.ifijeh@covenantuniversity.edu.ng

Received on 11.04.2020, Accepted on 14.10.2020

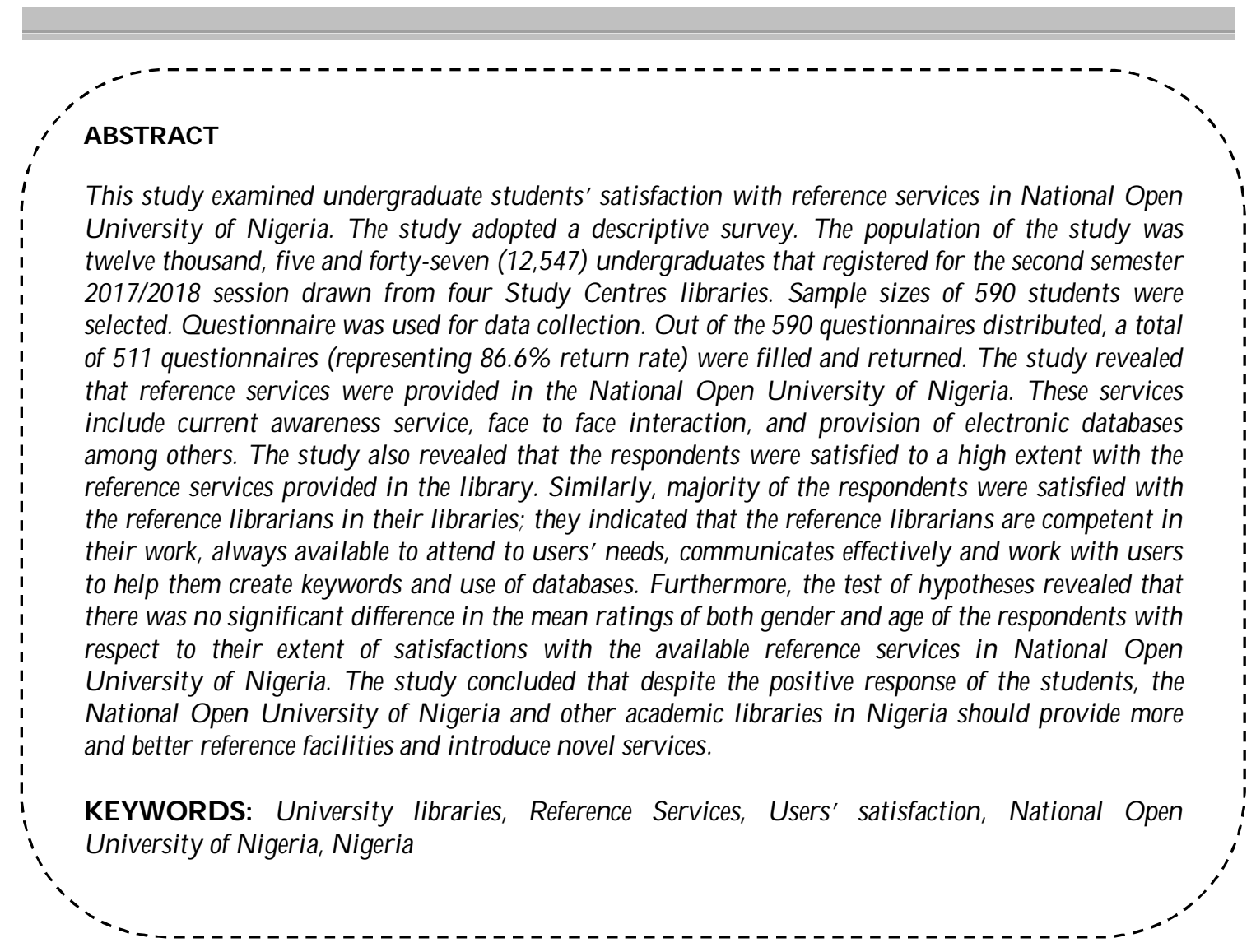




\section{INTRODUCTION}

The National Open University of Nigeria (NOUN) is a tertiary institution established to provide open and distance university education to all who wish to pursue university education in Nigeria through using open mode of instructional delivery. It was established in 1983 and suspended on $25^{\text {th }}$ April 1984. Eight years after the dosure, it was resuscitated on 1st of October, 2002 (NOUN, 2012). It was reopened to stop the proliferation of profit-oriented outreach programmes of many conventional universities scattered all over the country after the closure of the institution. Also, there was an urgent need to bring tertiary education to the doorstep of any individual who aspires to be educated irrespective of their age as it is stated in the university's mission statement, which is "to provide functional, cost-effective, flexible learning which adds lifelong value to quality education for all who seek knowledge" (NOUN, 2017). This mission statement can be achieved through well planned curriculum programmes, human resources and library support services. The National Open university of Nigeria (NOUN) libraries are set up to serve its parent institution which has over seventy - eight study centres scattered all over the country. National Open university of Nigeria has its headquarters at Abuja, where the University Librarian oversees and co-ordinate the study Centre libraries through the Study Centre Librarians. They send reports to the University Librarian on the activities going on in various study centre libraries. The NOUN libraries render a wide range of services including reference service.

One of the most important services rendered by libraries is reference service. Underscoring the importance of reference services, Madukoma (2015) observed reference services as fulfilling the purposes of information dissemination, hel ping the university library to achieve its crucial goals of pass on knowledge to library users. This goal can only be attained, when the library resources are exploited, efficiently and ably consulted. This can as well be achieved by educating users on proper usage of library resources. Rehman, Shafique \& Mahmood (2011) citing Pomerantz, Luo \& McClure (2006) opined that a quick study of a reference service help library management and concerned librarians with a clear understanding of how well the service is meeting its anticipated purposes and outcomes, how well the service is assisting students and university community meeting their information requests, and if the available information resources are producing the desired results. It is against this background that this paper examined users' satisfaction with reference services in National Open University of Nigeria.

\section{Objectives of the study}

- Find out the reference services available to the students of National Open University of Nigeria.

- Ascertain the extent to which students are satisfied with the available reference services in Open University of Nigeria.

- To find out how satisfied students are with the reference librarians

- To elicit information on students satisfaction with the reference facilities

\section{Research Questions}

1. What are the reference services available to the student of National Open University of Nigeria?

2. What are the extents to which students are satisfied with the available reference services in Open University of Nigeria?

3. To what extent are students satisfied with the reference librarians?

4. To what extent arestudents' satisfied with the reference facilities?

\section{Hypotheses}

1. There is no significant difference in the mean ratings of male and female student with respect to their extent of satisfactions with the available reference services in National Open University of Nigeria

2. There is no significant difference in the mean ratings of age ofstudent with respect to their extent of satisfactions with the available reference services in National Open University of Nigeria 


\section{LITERATURE REVIEW}

Libraries, irrespective of the type, exist to provide information for its community and the society at large (Lokeshappa, 2019). Saikia \& Gohain (2013) considered library collections including reference materials as the foundation of a library and a major source to meet the information needs of users. Namugera (2014) sees user' perception as the judgment and evaluation of reference collection performance and how it meets their needs. Many studies have been carried out on the user's perception of library reference collections.For example, Dollah \& Singh (2010) investigated the effectiveness of reference services by academic libraries in Malaysia, the findings showed that majority of the students indicated satisfaction and agreed that libraries in Malaysia are offering effective reference service. Similarly, Baharuddin \& Fadzil (2011) investigated perceptions of students reference services in Ptar Library UITM in Malaysia; majority of the respondents were satisfied with the quality of services rendered, also students al so indicated high level of satisfaction with reference interview, instant feedback, quality of the answer given and available reference sources with over 260 databases. The study of Uzoigwe \& Eze (2018) on reference services in Nigerian University Libraries revealed that majority of students indicated high level of satisfaction as reference services meet their information needs.

Okeke, Oghenetga and Nwabu (2013) carried out a study on academic libraries' reference and information services in Federal Polytechnic, Oko, Anambra State University, Nnamdi Azikiwe University and Madonna University, all in Anambra State, Nigeria. The findings of the study revealed that reference and information services provided by these libraries were not adequate; students indicated satisfaction with only photocopy of documents. Also, Madukoma (2015) revealed that reference services were insufficient and underutilized in Babcock University Library, Ogun State, Nigeria. A potiade, Oyewole and Belau (2015) in their study on availability and use of electronic reference services in Bells University in Ogun State, Nigeria, indicated that the main electronic reference services available were online chatting with the librarian, discussion over the phone with the librarian and email of questions to the librarian. Also, Uzoigwe and Eze (2018) in a study on perceived benefits of reference services in Nigerian University Libraries, established that majority of Nigerian university libraries were offering reference services and majority of students reported high level of satisfaction. They indicated provision of ICT in reference services, user education and access and e-journals were forms of reference services provided.

The role of the reference librarian in the provision of reference services cannot be over emphasized. Studies have also been carried out on users' perception of reference librarians. Kampen-Breit and Cooke (2015)'s study indicated that majority of students in Florida perceive reference librarians helpful but amazingly, these students were not willing to call for help as a result of their previous interactions with reference librarians, as their behaviour was considered offensive and irritating. Namugera (2014) observed that the majority of users perceive reference staff competent, they possess the skills and knowledge required to offer the desired reference library services in Makerere University Library, Uganda. Similarly, the study of Rehman, Shafique and Mahmood (2011) indicated that users expressed satisfaction with the reference staff. Also, in their study, Olajide \& Fabunmi (2011) indicated that users were satisfied with the reference librarians in University of Ado-Ekiti Library, Nigeria. In the same vein, Adeniran (2011) reported that users of Redeemer's University library, Nigeria were satisfied with the quality of reference staff of the library. Contrarily, Onifade and Adeniyi (2011)'s study show that users of Federal University of Agriculture, Abeokuta, Ogun State were not satisfied with the help received from library staff, as only one reference librarian was available to answer many users' queries, autting across a range of disciplines.

\section{METHODOLOGY}

This study adopted a descriptive survey. The population of the study was twelve thousand, five and forty-seven $(12,547)$ undergraduates that registered for the second semester 2018 session drawn from four Study Centres libraries. The study centre libraries are Benin (4,164), Enugu (2, 694,), Asaba

$(2,304)$ and Awka $(3,385)$. Yaro Yamane formular $\frac{N}{1+\left(N e^{2}\right)}$ Uzoagulu $(2011)$ was used in calculating the 
sample size of students from each study centre in order to have proportional representation. Sample sizes of 590 students were selected as follows: Benin (151), Enugu (144), Asaba (146) and Awka (149).students from the four study centre libraries.

Questionnaire was used for data collection. The questionnaire was constructed on a four-point Likert scale of Very High Extent(VHE,4Points); High Extent(HE, 3Points); Low Extent(LE, 2Points); Not A pplicable(NA, 1Point).Five hundred and ninety questionnaires were drawn and administered to the respondents comprising of undergraduates. A total of 511 questionnaires (representing $86.6 \%$ return rate) were filled and returned.

\section{Analysis of Data}

The data were organised in tables according to research questions, standard deviation (SD) and Mean $(\bar{X})$ scores. The Statistical Package for Social Science (SPSS) was used in analyzing the data generated from the respondents. Analyses values were assigned to the four response categories' and the mean was interpreted in line with the 4 point scale ranging from (4) highest to (1) the lowest. In decision making the lower limit of the high degree response category, which was 2.50 was used as cut off. Any item with a mean response of 2.50 and above was accepted as an influencing factor. ANOVA was used in testing the hypotheses, the results were based on a P-value of 0.05 benchmark. Where the level of significance is above 0.05 , it means that there is no significant relationship between the variables.

\section{DATA PRESENTATION AND ANALYSIS}

\begin{tabular}{|l|l|l|l|}
\hline Study Centre & $\begin{array}{l}\text { No. of Copies of questionnaires } \\
\text { administered }\end{array}$ & $\begin{array}{l}\text { Valid questionnaire } \\
\text { returned }\end{array}$ & Percentage \\
\hline ENUGU & 144 & 130 & 25.4 \\
\hline BENIN & 151 & 125 & 24.7 \\
\hline ASABA & 146 & 126 & 25.4 \\
\hline AWKA & 149 & 130 & 24.5 \\
\hline TOTAL & 590 & 511 & 100.0 \\
\hline
\end{tabular}

The rate returns according to study centre libraries were Benin (125), Enugu (130), Asaba (126) and Awka (130). A total number of five hundred and eleven questionnaires were returned from the undergraduates in the four study centre libraries under study.

Table 1: G ender of the respondents

\begin{tabular}{|l|l|l|}
\hline Gender & Frequency & Per cent \\
\hline Male & 193 & $37.8 \%$ \\
\hline Female & 318 & $62.2 \%$ \\
\hline Total & 511 & $100.0 \%$ \\
\hline
\end{tabular}

The respondents percentage figure on their gender showed that the highest number of respondents from the four study centre libraries under study are females $318(62.2 \%$ while males were $193(37.8 \%)$.

Table 2: Age group of the respondents

\begin{tabular}{|l|l|l|}
\hline Age & Frequency & Per cent \\
\hline $18-22$ & 252 & $49.3 \%$ \\
\hline $23-27$ & 166 & $32.5 \%$ \\
\hline $28-32$ & 47 & $9.2 \%$ \\
\hline 33 and above & 46 & $9.0 \%$ \\
\hline Total & $\mathbf{5 1 1}$ & $\mathbf{1 0 0 . 0} \%$ \\
\hline
\end{tabular}

The above result showed that the highest age group of the respondents are in the range of $18-22$ 
(252) with a percentage of $49.3 \%$, followed by 23 - 27 years (166) $32.5 \%$, $28-32$ years (47) $9.2 \%$ and lastly 33yrs and above (46) with $9.0 \%$.

Research Question 1: What are the reference services available to the students of National Open University?

Table 3: Reference services available to the students of $\mathrm{N}$ ational $\mathrm{O}$ pen University

\begin{tabular}{|l|l|l|l|l|l|}
\hline \multirow{2}{*}{ Item statement } & \multicolumn{2}{|l|}{ Available } & \multicolumn{2}{l|}{ N ot Available } & D ecision \\
\cline { 2 - 6 } & Freq. & $\%$ & Freq. & $\%$ & \\
\hline Face to face Interaction & 317 & 62.0 & 194 & 38.0 & Available \\
\hline Library Handouts and Guides on library use & 356 & 69.7 & 155 & 30.3 & Available \\
\hline Magazines/ Journals & 386 & 75.5 & 125 & 24.5 & Available \\
\hline Current awareness Services & 304 & 59.5 & 207 & 40.5 & Available \\
\hline Electronic Databases & 360 & 70.5 & 151 & 29.5 & Available \\
\hline Library based reference Interaction & 432 & 84.5 & 79 & 15.5 & Available \\
\hline Email based reference interaction & 306 & 59.9 & 205 & 40.1 & Available \\
\hline
\end{tabular}

The findings reveal ed that, all the reference services listed above are available to students of $\mathrm{National}$ Open University in the four study centre libraries. The result also showed that current awareness services $(40,5 \%)$ is the highest rated reference services available to these undergraduates, followed by face to face interaction (38\%), library hand outs and guides on library use (30.3\%), Electronic Databases (29.5\%) whilethe less is Library based reference Interaction (15.5\%).

Research Question 2: What is the extent to which students are satiffied with the available reference services in National Open University of Nigeria?

Table 4: Mean and Standard Deviation of the extent of satisfactions with the available reference services

\begin{tabular}{|c|c|c|c|c|c|c|c|c|c|c|c|c|}
\hline \multirow[t]{2}{*}{ S.N. } & \multirow[t]{2}{*}{ I tem statement } & \multicolumn{2}{|c|}{$\begin{array}{l}\text { Enugu } \\
\mathrm{N}=130\end{array}$} & \multicolumn{2}{|c|}{$\begin{array}{l}\text { Asaba } \\
\mathrm{N}=126\end{array}$} & \multicolumn{2}{|c|}{$\begin{array}{l}\text { Awka } \\
\mathrm{N}=130\end{array}$} & \multicolumn{2}{|c|}{\begin{tabular}{|l|} 
Benin \\
$\mathbf{N}=125$ \\
\end{tabular}} & \multicolumn{2}{|c|}{$\begin{array}{l}\text { Overall } \\
\mathrm{N}=511\end{array}$} & \multirow[t]{2}{*}{ Decision } \\
\hline & & $\overline{\bar{X}}$ & SD & $\bar{X}$ & SD & $\bar{X}$ & SD & $\bar{X}$ & SD & $\bar{X}$ & SD & \\
\hline 1 & Face to face Interaction & 2.48 & 1.04 & 3.01 & 0.94 & 2.52 & 1.06 & 3.01 & 0.99 & 2.75 & 1.04 & $\mathrm{HE}$ \\
\hline 2 & $\begin{array}{l}\text { Library Handouts and } \\
\text { Guides on library use }\end{array}$ & 2.55 & 0.92 & 2.95 & 0.87 & 2.63 & 0.94 & 2.93 & 0.88 & 2.76 & 0.92 & $\mathrm{HE}$ \\
\hline 3 & Magazines/ Journals & 2.45 & 0.91 & 2.97 & 0.80 & 2.52 & 0.93 & 2.93 & 0.82 & 2.71 & 0.89 & $\mathrm{HE}$ \\
\hline 4 & $\begin{array}{l}\text { Current awareness } \\
\text { Services }\end{array}$ & 2.38 & 0.94 & 2.92 & 0.88 & 2.48 & 0.94 & 2.92 & 0.90 & 2.67 & 0.95 & $\mathrm{HE}$ \\
\hline 5 & Electronic Databases & 2.41 & 0.92 & 2.79 & 0.96 & 2.49 & 0.95 & 2.76 & 0.99 & 2.61 & 0.97 & $\mathrm{HE}$ \\
\hline 6 & $\begin{array}{l}\text { Library based reference } \\
\text { Interaction }\end{array}$ & 2.33 & 0.91 & 2.80 & 0.90 & 2.42 & 0.95 & 2.77 & 0.93 & 2.58 & 0.94 & $\mathrm{HE}$ \\
\hline 7 & $\begin{array}{l}\text { Email based reference } \\
\text { interaction }\end{array}$ & 2.27 & 0.92 & 2.67 & 0.98 & 2.33 & 0.94 & 2.61 & 1.00 & 2.47 & 0.97 & LE \\
\hline & Cluster M ean \& SD & 2.41 & 0.94 & 2.87 & 0.90 & 2.48 & 0.96 & 2.85 & 0.93 & 2.65 & 0.95 & HE \\
\hline
\end{tabular}

VHE - Very Highly Extent, HE-Highly Extent, LE-Low Extent, NA - Not A pplicable

Table 4 above indicated that the students of National Open University to a high extent are satisfied with the available reference services available to them with the cluster mean ( $\bar{X} 2.95)$ and a standard deviation of (SD 0.95). The respondents arehighly satisfied with library handouts and guides on library use ( $\bar{X} 2.76, \mathrm{SD}$ 0.92), followed by the face to face interaction ( $\bar{X} 2.75$, SD 1.04 ), Magazines/ Journals $\left(\bar{X}_{2.71}, \mathrm{SD} 0.89\right)$, Current awareness Services $\left(\bar{X}_{2.67}\right.$, SD 0.89) while their satisfactions on the Email based reference interaction is to a low extent ( $\bar{X} 2.47, \mathrm{SD} 0.97)$. 
Research Question 3: To what extent are students satisfied with the reference librarians?

Table 5: M ean and Standard Deviation of the extent of satisfactions students are with the reference librarians

\begin{tabular}{|c|c|c|c|c|c|c|c|c|c|c|c|c|}
\hline \multirow[t]{2}{*}{ S.N. } & \multirow[t]{2}{*}{ Item statement } & \multicolumn{2}{|c|}{$\begin{array}{l}\text { Enugu } \\
N=130\end{array}$} & \multicolumn{2}{|c|}{$\begin{array}{l}\text { Asaba } \\
\mathrm{N}=126\end{array}$} & \multicolumn{2}{|c|}{$\begin{array}{l}\text { A wka } \\
\text { N }=130\end{array}$} & \multicolumn{2}{|c|}{\begin{tabular}{|l} 
Benin \\
$\mathrm{N}=\mathbf{1 2 5}$
\end{tabular}} & \multicolumn{2}{|c|}{$\begin{array}{l}\text { Overall } \\
\mathrm{N}=511\end{array}$} & \multirow[t]{2}{*}{ Decision } \\
\hline & & $\bar{X}$ & SD & $\bar{X}$ & SD & $\overline{\bar{X}}$ & SD & $\overline{\bar{X}}$ & SD & $\bar{X}$ & SD & \\
\hline 1 & $\begin{array}{l}\text { Reference Librarians are } \\
\text { competent with their } \\
\text { work }\end{array}$ & 2.72 & 0.86 & 3.21 & 0.76 & 2.78 & 0.89 & 3.15 & 0.77 & 2.96 & 0.85 & \\
\hline 2 & \begin{tabular}{|l|} 
Reference Librarians \\
communicate effectively
\end{tabular} & 2.76 & 0.85 & 3.22 & 0.78 & 2.78 & 0.86 & 3.15 & 0.81 & 2.98 & 0.85 & \\
\hline 3 & $\begin{array}{l}\text { Reference Librarians are } \\
\text { always available to } \\
\text { attend to users' need }\end{array}$ & 2.75 & 0.90 & 3.13 & 0.81 & 2.78 & 0.92 & 3.05 & 0.84 & 2.93 & 0.88 & \\
\hline 4 & $\begin{array}{l}\text { Reference Librarians } \\
\text { work with users to help } \\
\text { them create keywords for } \\
\text { leocting and using } \\
\text { databases }\end{array}$ & 2.67 & 0.93 & 3.04 & 0.78 & 2.71 & 0.96 & 3.03 & 0.82 & 2.86 & 0.89 & \\
\hline & Cluster M ean \& SD & 2.73 & 0.89 & 3.15 & 0.78 & 2.76 & 0.91 & 3.10 & 0.81 & 2.93 & \begin{tabular}{|l|}
0.87 \\
\end{tabular} & \\
\hline
\end{tabular}

Table 5 shows that that the majority of the respondents are satisfied with the reference librarians showing that the reference librarians are competent in their work, al ways available to attend to users' needs, communicates effectively and work with users to help them create keywords and use of databases.

Research Q uestion 4: To what extent are students' satisfied with the reference facilities?

Table 6: M ean and Standard D eviation of students' satisfaction with the reference facilities

\begin{tabular}{|c|c|c|c|c|c|c|c|c|c|c|c|c|}
\hline \multirow[t]{2}{*}{ S.N. } & \multirow[t]{2}{*}{ Item statement } & \multicolumn{2}{|c|}{$\begin{array}{l}\text { Enugu } \\
\mathrm{N}=\mathbf{1 3 0}\end{array}$} & \multicolumn{2}{|c|}{$\begin{array}{l}\text { Asaba } \\
\mathrm{N}=126\end{array}$} & \multicolumn{2}{|c|}{$\begin{array}{l}\text { Awka } \\
\mathrm{N}=130\end{array}$} & \multicolumn{2}{|c|}{$\begin{array}{l}\text { Benin } \\
N=125\end{array}$} & \multicolumn{2}{|c|}{\begin{tabular}{|l} 
Overall \\
$\mathrm{N}=511$
\end{tabular}} & \multirow[t]{2}{*}{ Decision } \\
\hline & & $X$ & SD & $\bar{X}$ & SD & $X$ & SD & $\bar{X}$ & SD & $\bar{X}$ & SD & \\
\hline 1 & $\begin{array}{l}\text { There are air } \\
\text { condition/ fans for } \\
\text { cooling of the references } \\
\text { section }\end{array}$ & 2.82 & 0.87 & 3.14 & 0.78 & 2.91 & 0.90 & 3.06 & 0.81 & 2.98 & 0.85 & $\mathrm{HE}$ \\
\hline 2 & $\begin{array}{l}\text { The reference section } \\
\text { provides computers to } \\
\text { enhance the sue of } \\
\text { electronic references } \\
\text { sources }\end{array}$ & 2.60 & 0.92 & 2.79 & 0.92 & 2.65 & 0.96 & 2.86 & 0.90 & 2.72 & 0.93 & $\mathrm{HE}$ \\
\hline 3 & $\begin{array}{l}\text { There are computers in } \\
\text { the reference section for } \\
\text { easy accessibility of } \\
\text { reference materials }\end{array}$ & 2.64 & 0.90 & 3.10 & 0.81 & 2.67 & 0.92 & 2.98 & 0.85 & 2.84 & 0.89 & $\mathrm{HE}$ \\
\hline 4 & $\begin{array}{l}\text { Thelibrary allows me to } \\
\text { photocopy reference } \\
\text { materials }\end{array}$ & 2.66 & 0.87 & 3.06 & 0.87 & 2.72 & 0.92 & 3.02 & 0.93 & 2.86 & 0.91 & HE \\
\hline 5 & $\begin{array}{l}\text { Reference collection } \\
\text { satisfy my information }\end{array}$ & 2.73 & 0.88 & 3.30 & 0.77 & 2.81 & 0.88 & 3.27 & 0.86 & 3.02 & 0.89 & HE \\
\hline
\end{tabular}




\begin{tabular}{|l|l|l|l|l|l|l|l|l|l|l|l|l|}
\hline & needs & & & & & & & & & & & \\
\hline 6 & $\begin{array}{l}\text { Thelibrary web pages are } \\
\text { informative enough as it } \\
\text { concerns ereference } \\
\text { information }\end{array}$ & 2.56 & 0.85 & 3.01 & 0.66 & 2.60 & 0.88 & 2.99 & 0.71 & 2.79 & 0.81 & HE \\
\hline 7 & $\begin{array}{l}\text { The library has sufficient } \\
\text { electronic references } \\
\text { sources }\end{array}$ & 2.67 & 0.91 & 3.07 & 0.75 & 2.71 & 0.92 & 3.06 & 0.81 & 2.87 & 0.87 & HE \\
\hline 8 & $\begin{array}{l}\text { The reference sources are } \\
\text { current }\end{array}$ & 2.61 & 0.88 & 3.02 & 0.74 & 2.66 & 0.90 & 3.02 & 0.79 & 2.82 & 0.85 & HE \\
\hline 9 & $\begin{array}{l}\text { The available reference } \\
\text { resources address my } \\
\text { reference questions }\end{array}$ & 2.58 & 0.82 & 3.11 & 0.77 & 2.62 & 0.86 & 3.04 & 0.82 & 2.83 & 0.85 & HE \\
\hline 10 & $\begin{array}{l}\text { The library has sufficient } \\
\text { print reference sources }\end{array}$ & 2.67 & 0.84 & 3.10 & 0.79 & 2.68 & 0.88 & 3.05 & 0.84 & 2.87 & 0.86 & HE \\
\hline & Cluster Mean \& SD & 2.67 & 0.88 & 3.09 & 0.79 & 2.72 & 0.90 & 3.05 & 0.83 & 2.88 & 0.87 & HE \\
\hline
\end{tabular}

VHE - Very Highly Extent, HE-Highly Extent, LE-Low Extent, NA - Not A pplicable

Table 6 presents data generated on the students are satisfied with the reference facilities. Result shows that students are satisfied with the reference facilities provided in reference sections in the study centre libraries. The reference facilities are air condition/ fans for cooling ( $\bar{X} 2.98$, SD 0.85 ), library has sufficient print and electronic reference sources ( $\bar{X} 2.87$, SD 0.86), students are allowed to photocopy reference sources ( $\bar{X} 2.86$, SD 0.91 ), there are computers in the reference section for easy accessibility of reference materials ( $\bar{X} 2.84$, SD 0.89 ), library web pages are informative enough as it concerns ereference information $(2.79$, SD 0,81$)$ and above all the students to highly extent accepted that reference collection satisfy my information needs ( $\bar{X}$ 3.02, SD0.89). The cluster mean ( $\bar{X}$ 2.88, SD 0.87) indicated that thesestudents are to high extent satisfied with the libraries references facilities.

$H_{\text {o1: }}$ There is no significant difference in the mean ratings of male and female student with respect to their extent of satisfactions with the available reference services in National Open University of Nigeria

Table 7: Independent t-test analysis in the mean responses of male and female students with respect to their extent of satisfactions with the available reference services

\begin{tabular}{|l|l|l|l|l|l|l|l|}
\hline & $\mathbf{N}$ & $\mathbf{X}$ & SD & df & t & $\begin{array}{l}\text { Significance (2- } \\
\text { tailed) P }\end{array}$ & D ecision \\
\hline Male & 193 & 2.59 & 0.72 & 509 & -1.429 & 0.154 & No significant \\
\hline Female & 318 & 2.69 & 0.71 & & & & \\
\hline
\end{tabular}

$\mathrm{N}=$ Population, $\mathrm{X}=\mathrm{M}$ ean, $\mathrm{SD}=\mathrm{Standard} \mathrm{Deviation}, \mathrm{df}=$ degree of freedom, $\mathrm{p}=$ probability level of significance, $\mathrm{t}=$ cal culated value

From Table 7, it can be seen that male respondents are 209 with mean rating of 2.59 and standard deviation of 0.72 , while the female respondents are318 with mean rating of 2.69 with standard deviation of 0.71 . t calculated value is -1.429 with df of 509 and Sig. (2-tailed) $=0.154=P$. Since $P$ is greater than 0.05 , the null hypothesis is accepted.

$\mathbf{H}_{\text {o2: }}$ There is no significant difference in the mean ratings of age of students with respect to their extent of satisfactions with the available reference services in National Open University of Nigeria 
Table 8: ANOVA of the significant difference between the mean responses of students with respect to their extent of satisfactions with the available reference services in $N$ ational Open University of Nigeria

\begin{tabular}{|l|l|l|l|l|l|l|}
\hline & Sum of Squares & df & M ean Square & F & Sig. & Decision \\
\hline Between Groups & 2.824 & 3 & 0.941 & 1.859 & 0.135 & Not Significant \\
\hline Within Groups & 256.636 & 507 & 0.506 & & & \\
\hline Total & 259.459 & 510 & & & & \\
\hline
\end{tabular}

Result in hypothesis in the above table, is the ANOVA result of the difference between the mean responses of students with respect to their extent of satisfactions with the available reference services in National Open University of Nigeria. The result showed that an f-ratio of 1.859 was obtained with a probability value of 0.135 . Since the probability value of 0.135 is greater than 0.05 set as level of significance for testing the hypothesis, it means that the null hypothesis which stated that there is no significant difference in the mean ratings of age of students with respect to their extent of satisfactions with the available reference services in National Open University of Nigeria is not rejected. The Inference drawn is that there is no significant difference in the mean ratings of age of students with respect to their extent of satisfactions with the available reference services in National Open University of Nigeria.

\section{SUMM ARY OF FINDINGS AND CONCLUSION}

The study revealed that reference services were provided in the National Open University of Nigeria. These services include current awareness service, face to face interaction, and provision of electronic databases among others. The study also revealed that the respondents were satisfied to a high extent with the reference services provided in the library. Similarly, majority of the respondents were satisfied with the reference librarians in their libraries; they indicated that the reference librarians are competent in their work, always available to attend to users' needs, communicates effectively and work with users to help them create keywords and use of databases. Furthermore, the test of hypotheses revealed that there was no significant difference in the mean ratings of both gender and age of the respondents with respect to their extent of satisfactions with the available reference services in National Open University of Nigeria. These findings are in tandem with previous studies as earlier discussed in the review of literature (Dollah and Singh, 2010; Baharuddin and Fadzil, 2011; Uzoigwe and Eze, 2018).

In spite of the findings of this study, the National Open University of Nigeria and other academic libraries must strive to improve on their services in order to get more patronage and increase the level of satisfaction among users. They need to acquire more and better facilities and introduce novel services.

\section{REFERENCES}

1. Adeniran, P. (2011) User satisfaction with academic libraries services: Academic staff and students perspectives International Journal of Library and Information Science, 3(10), 209-216, Retrieved from online http:/ / www.academicjournals.org/ ijlis

2. A potiade, J.K., Oyewole, O. and Belau, A.O. (2015). Availability, Accessibility and Utilization of Electronic Reference Services by Undergraduate Students in Bells University, Ogun State, Nigeria. Information and Knowledge M anagement, 5(9), 40- 46

3. Baharuddin, M.F. \& Fadzil. F.H. (2011) Users' Perceptions Regarding Digital Reference Services in Ptar Library UiTM. Perkhidmatan Perpustakaan, 348- 359

4. Dollah, W. \& Singh, D. (2010). Determining the Effectiveness of Digital Reference Services in Malaysian Academic Libraries. The Reference Librarian, 51:329-354, 10.1080/ 02763877.2010.501427

5. Kampen-Breit, D. J. \& Cooke, R. (2015).Do They Think We're the Frenemy?: Examining Student Anxiety and Service Perception in Today's Academic Libraries. Library Leadership and $M$ anagement, (30)1,1-16 
6. Lokeshappa, H. (2019) Role of Libraries in Disseminating Information to the Society: an Overview

Library Progress (International), 39 (2), 409 - 413.

7. Madukoma, E. (2015). Users' perception of electronic reference services in Babcock University Library, Ilishan-Remo, Ogun State, Nigeria. IFLA. Retrieved from http:/ / library.ifla.org/ 1302/ 1/ s012-madukoma-en.pdf

8. Olajide, O. \& Fabunmi, F.A. (2011). Lecturers' Perception of the Adequacy of Resources and Services of University of Ado-Ekiti Library. Library Philosophy and Practice. Retrieved from http:/ / unllib.unl.edu/ LPP/

9. Okeke, I.E., Oghenetga, L.U. \&Nwabu, E.C. (2013). Students' attitude towards the use of reference and information services (RIS) in academic Libraries in Nigeria. International Journal of Library and Information Science, 5(10), 335-341 DOI: 10.5897/ IJLIS2013.0379

10. Onifade F.N. and Adeniyi O.S. (2011). Reference Services in a University Library: Awareness and Perception of UndergraduateStudents, Pacific N orthwest Library A ssociation Quarterly 75, 3

11. Namugera, L. (2014). Users' awareness, perceptions and usage of Makererelibrary services in the main and selected branch libraries.Qualitative and Quantitative M ethods in Libraries (Q Q M L) , 3, $741-758$

12. Rehman, S.U., Shafique, F. \& Mahmood, K. (2011). A Survey of User Perception and Satisfaction with Reference Services in University Libraries of Punjab. Library Philosophy and Practice. 624 Retrieved fromhttp:/ / digitalcommons.unl.edu/ libphilprac/ 624

13. Saikia, M. \& Gohain, A. (2013). Use and user's satisfaction in library resources and services: A study in Tezpur University (India). International Journal of Library and Information Science, 5(6):167-175 DOI: 10.5897/ IJLIS2012.0328

14. Uzoigwe C.U. \& Eze J.U. (2018).The Perceived Benefits of Electronic/ digital Reference Services in Nigerian University Libraries: a survey. International Journal of Knowledge Content Development \& Technology, 8 (2), 49-65

15. Uzoagulu, A. E. (2011). Practical guide to writing research project report in tertiary institutions. Enugu, NG: Cheston Publishers. 